\title{
Comparison of Three Temperatures for the Hatching Phase in the Artificial Incubation of Red-legged Partridge (Alectoris rufa) Eggs
}

\section{-Author(s)}

\section{González-Redondo P}

Díaz-Merino R'

Departamento de Ciencias Agroforestales, Escuela Técnica Superior de Ingeniería Agronómica, Universidad de Sevilla, 41013 Sevilla, Spain

\section{ABSTRACT}

This study aimed at investigating the effects of three incubation temperatures during the hatching period on egg weight loss, hatchability, chick weight at hatching and length of the incubation period of redlegged partridge (Alectoris rufa) under artificial incubation. One hundred and fifty eggs obtained from a red-legged partridge game farm were randomly allocated to three batches of 50 eggs each. Eggs were incubated at $37.8^{\circ} \mathrm{C}$ during the first 20 days, and subsequently at 37.0 , 37.4 or $37.8^{\circ} \mathrm{C}$ until hatching. Fertility was $74.7 \%$ and a good hatching performance was obtained, characterized by $85.7 \%$ hatchability, $9.1 \%$ egg weight loss after 20 days of incubation, $13.8 \pm 0.1 \mathrm{~g}$ chick weight at hatching, and 23.2 \pm 0.1 days incubation length. Hatchability, egg weight loss after 20 days of incubation, and length of the incubation period were not affected by incubation temperature during the hatching period. However, hatching synchrony improved when the incubation temperature was increased from 37.0 to $37.8^{\circ} \mathrm{C}(p<0.05)$. Thus, hatching distribution became very leptokurtic and very positively skewed with the increase in incubation temperature during the hatching phase. In conclusion, higher hatching synchrony can be achieved in $A$. rufa when setting temperatures within the range 37.0 to $37.8^{\circ} \mathrm{C}$ to incubate eggs during the hatching period. Consequently, incubation temperature management during the hatching phase may have a direct impact on hatching synchrony and hatchling management.

\section{INTRODUCTION}

In order to provide birds to restock hunting reserves, the red-legged partridge (Alectoris rufa) is reared in several Mediterranean countries (mainly Spain, Portugal, France, and Italy), which has led to a welldeveloped subsector of game farms (Sánchez García-Abad et al., 2009; González-Redondo et al., 2010). One of the keys of red-legged partridge farm productivity is egg handling and incubation, which have been recently being investigated to review and improve empirical farmer's practices (González-Redondo \& De la Rosa Sánchez, 2009; González-Redondo, 2010; Gómez-de-Travecedo et al., 2014a, 2014b, 2014c). However, several aspects of the artificial incubation of $A$. rufa eggs still need to be scientifically evaluated.

In particular, incubation temperature strongly influences hatchability and the livability of chicks. In this regard, literature studies recommend incubating red-legged partridge eggs at temperatures ranging from 37.7 to $38.0^{\circ} \mathrm{C}$ during the first $20-21 \mathrm{~d}$ of incubation, and subsequently transferring them to a hatcher, where temperature is lowered between $0.2-0.3$ and $1{ }^{\circ} \mathrm{C}$ and set at 37.2 to $37.5^{\circ} \mathrm{C}$ (Llauradó, 1987; Cancho, 1991; Setién, 1991; Saperas, 1992; García-Martín \& Dalmau, 2003), until hatching occurs on day 23-24 (González-Redondo et al., 2012). The 
incubation temperature is reduced during the hatching phase because the heating needs of the embryos are lower at this late stage of incubation (Decuypere \& Michels, 1992; Molenaar et al., 2010). However, optimal incubation temperature during the hatching period of $A$. rufa has not been precisely established by scientific studies yet. Therefore, this study was designed to investigate the effects of three incubation temperatures during the hatching period (37.0, 37.4 and $37.8^{\circ} \mathrm{C}$ ) on the hatchability, egg weight loss, and length of the incubation period of artificially incubated red-legged partridge eggs.

\section{MATERIAL AND METHODS}

\section{Breeder flock and husbandry}

The hatching eggs used in this trial were obtained from a red-legged partridge game farm located in Santa Cruz (province of Cordoba, southern Spain). Eggs derived from 2-year-old breeders that were fed ad libitum a balanced commercial feed containing $2800 \mathrm{kcal}$ metabolizable/kg and 20\% crude protein, and were kept in pairs in outdoor cages measuring $40 \times 100 \mathrm{~cm}$. During the reproductive resting period, breeders were subjected to natural lighting. From midDecember, artificial lighting was supplied, increasing the photoperiod by a quarter of an hour every $3 \mathrm{~d}$ until a total photoperiod (natural+artificial light) of $16 \mathrm{~h}$ of light was reached by the end of January.

\section{Experimental procedure}

On May 31, 150 recently-laid hatching eggs were collected and randomly allocated to three groups of 50 eggs each. Twelve hours before being loaded in the incubator, all eggs were pre-warmed at $22-23^{\circ} \mathrm{C}$ and $45-50 \%$ relative humidity $(\mathrm{RH})$ in the room where the incubator was located. All the experimental batches were subsequently loaded into an incubator (Masalles HS25 ${ }^{\circledR}$, Masalles, Ripollet, Spain) on the same date (June 1). The incubator was set at $37.8^{\circ} \mathrm{C}$ and $55 \% \mathrm{RH}$, and eggs were automatically turned every hour. On day 20 of incubation, each of the experimental batches was transferred to an independent hatcher set at different temperatures: $37.0^{\circ} \mathrm{C}\left(1-2 \mathrm{SA}^{\circledR}\right.$ hatcher, Maino EnricoAdriano S.n.c., Oltrona di San Mamette, Italy), $37.4^{\circ} \mathrm{C}$ (MG $50 \mathrm{H}^{\circledR}$ hatcher, FIEM S.n.c., Guanzate, Italy), or $37.8^{\circ} \mathrm{C}$ (Masalles $\mathrm{HS} 25^{\circledR}$ hatcher, Masalles, Ripollet, Spain). In order to maintain the other incubation parameters constant among experimental treatments, on day 20 of incubation RH was increased to $75 \%$ and turning of eggs was stopped in all batches.

\section{Parameters evaluated}

All eggs were individually weighed before incubation and on day 20 of incubation. Egg weight loss after $20 \mathrm{~d}$ of incubation was calculated as a percentage of initial egg weight. After the incubation period, the numbers of hatched chicks and unhatched eggs were recorded, and unhatched eggs were broken to determine true fertility (Ernst et al., 2004). The length of the incubation period was calculated as the difference between the date eggs were set in the incubator and hatching date of each individual egg, determined through hatching controls carried out every $12 \mathrm{~h}$. All chicks were individually weighed at hatching.

\section{Statistical analysis}

Differences in fertility, hatchability of total eggs set, and hatchability of fertile eggs, as a function of the incubation temperature during the hatching period, were statistically analyzed using contingency tables on which Pearson's $\chi^{2}$ tests were performed. Statistical differences among treatments in initial and final egg weights, fertile egg weight loss on $20 \mathrm{~d}$ of incubation, chick weight at hatching, and length of the incubation period were analyzed by one-way ANOVA in case of homoscedasticity, and by Kruskal-Wallis tests in case of heteroscedasticity. When differences among treatments were significant, means were separated using Duncan's multiple range tests at 0.05 significance level. Pearson correlation was applied to analyze the ratio between egg weight before incubation and chick weight at hatching. The descriptive statistical parameters, including maximum and minimum values, coefficient of variation, and skewness $\left(g_{1}\right)$ and kurtosis $\left(g_{2}\right)$ coefficients were calculated for the variable incubation length. Differences in the variance of the length of the incubation period among treatments were also analyzed. The values of the quantitative variables were expressed as mean \pm standard error of the mean. The analyses were performed using SPSS 15.0 statistical package (SPSS Inc., Chicago, USA).

\section{RESULTS}

Mean fertility was $74.7 \%$, hatchability of the total number of incubated eggs was $64.0 \%$, and hatchability of the fertile eggs reached $85.7 \%$ (Table 1). No differences were observed among the experimental treatments in the fertility of incubated eggs $(p=0.076$.), hatchability of total eggs set $(p=0.088)$, or in hatchability of fertile eggs $(p=0.755)$. 
Table 1 - Fertility and hatchability of red-legged partridge eggs according to the incubation temperature during the hatching phase.

\begin{tabular}{lccccccc}
\hline $\begin{array}{l}\text { Temperature during } \\
\text { hatching period } \\
\left({ }^{\circ} \mathrm{C}\right)\end{array}$ & $\begin{array}{c}\text { Number of eggs } \\
\text { Incubated }\end{array}$ & Fertile & Hatched & $\begin{array}{c}\text { Fertility } \\
(\%)\end{array}$ & $\begin{array}{c}\text { Hatchability of the } \\
\text { eggs set }^{2} \\
(\%)\end{array}$ & $\begin{array}{c}\text { Hatchability of the fertile } \\
\text { eggs }^{3} \\
(\%)\end{array}$ \\
\hline 37.0 & 50 & 35 & 30 & 70.0 & 60.0 & 85.7 \\
37.4 & 50 & 43 & 38 & 86.0 & 76.0 & 88.4 \\
37.8 & 50 & 34 & 28 & 68.0 & 56.0 & 82.4 \\
\hline Total & 150 & 112 & 96 & 74.7 & 64.0 & 85.7 \\
p value & & & & 0.076 & 0.088 & 0.755 \\
\hline
\end{tabular}

'Percentage of incubated eggs that were fertile. ${ }^{2}$ Percentage of incubated eggs that hatched. ${ }^{3}$ Percentage of fertile eggs that hatched.

The mean weight of the fertile eggs before incubation was $19.51 \pm 0.13 \mathrm{~g}$. Eggs incubated during the hatching period at $37.4^{\circ} \mathrm{C}$ were lighter than those from the other treatments (Table 2; $p=0.008$ ). After d 20 of incubation, average weight loss of the fertile eggs amounted to $9.08 \pm 0.18 \%$ of their initial weight, without any differences among experimental batches (Table 2; $p=0.527$ ).

Mean chick weight at hatching was $13.79 \pm 0.11 \mathrm{~g}$, and differences among the experimental treatments were detected, although there was no linear progression (Table 3; $p=0.040$ ). Moreover, chick weight at hatching was positively correlated with the initial egg weight $(r=0.810, p<0.001)$.

The mean incubation period lasted $23.23 \pm 0.05 \mathrm{~d}$ and was independent of the incubation temperature during the hatching period, although it showed a marginal trend to decrease with higher incubation temperatures during the hatching phase (Table 3; $p<0.052)$. Increasing the incubation temperature from 37.0 to $37.8^{\circ} \mathrm{C}$ during the hatching period led to an increase in the hatching synchrony, as illustrated by a reduction in variance $(p<0.05)$, in the coefficient of variation and in the range of the incubation length (Table 3). In fact, hatching was reduced from $2.5 \mathrm{~d}$ span in the batch of eggs incubated at $37.0^{\circ} \mathrm{C}$ to a $1.5 \mathrm{~d}$ span in the batch incubated at $37.8^{\circ} \mathrm{C}$. Thus, hatching distribution was very leptokurtic and very positively skewed with the increase in the incubation temperature during the hatching period (Table 3).

\section{DISCUSSION}

The mean values of fertility, hatchability of eggs set, and hatchability of fertile eggs found in this trial were within the ranges described in literature for $A$. rufa under farming conditions ( 50.2 to $89.7 \%, 30.6$ to $86.4 \%$ and 57.5 to $91.6 \%$, respectively; Bagliacca et al., 1988; Paci et al., 1992; González-Redondo, 2006, 2010; Mourão et al., 2010; Gómez-de-Travecedo et al., 2014a, 2014b, 2014c). As no differences were found among the experimental batches for these parameters, it can be considered that, in all treatments, incubation conditions were suitable in terms of hatchability. In fact, it is known that in A. rufa farming (Setién, 1991) and in other poultry species (French, 2000) excessive incubation temperature, even for short periods, causes an abnormal increase in embryo mortality, which did not occur in this trial, suggesting that the three incubation temperatures tested for the hatching phase appeared to be adequate for red-legged partridges.

Mean egg weight and egg weight loss of recentlylaid fertile eggs during the first $20 \mathrm{~d}$ of incubation agreed with those described for red-legged partridges under game farming conditions (González-Redondo, 2010; Mourão et al., 2010; Gómez-de-Travecedo et

Table 2 - Egg weight losses during incubation in red-legged partridge fertile eggs according to incubation temperature during the hatching phase (mean \pm standard error of the mean).

\begin{tabular}{|c|c|c|c|c|}
\hline $\begin{array}{l}\text { Temperature during } \\
\text { hatching period } \\
\left({ }^{\circ} \mathrm{C}\right)\end{array}$ & $\begin{array}{c}\text { the } \begin{array}{c}\text { Number of fertile } \\
\text { eggs }\end{array} \\
\text {. }\end{array}$ & $\begin{array}{l}\text { Egg weight before incubation } \\
\qquad(\mathrm{g})\end{array}$ & $\begin{array}{l}\text { Egg weight at } 20 \mathrm{~d} \text { of } \\
\text { incubation } \\
(\mathrm{g})\end{array}$ & $\begin{array}{c}\text { Egg weight loss after } 20 \mathrm{~d} \text { of } \\
\text { incubation } 1 \\
(\%)\end{array}$ \\
\hline 37.0 & 35 & $19.94 \pm 0.27^{a}$ & $18.08 \pm 0.27^{a}$ & $9.38 \pm 0.44$ \\
\hline 37.4 & 43 & $19.03 \pm 0.18^{b}$ & $17.30 \pm 0.18^{b}$ & $9.10 \pm 0.19$ \\
\hline 37.8 & 34 & $19.67 \pm 0.20^{a}$ & $17.95 \pm 0.21^{\mathrm{a}}$ & $8.75 \pm 0.27$ \\
\hline Total & 112 & $19.51 \pm 0.13$ & $17.74 \pm 0.13$ & $9.08 \pm 0.18$ \\
\hline$p$ value & & 0.008 & 0.022 & 0.527 \\
\hline
\end{tabular}

'Values are expressed as a percentage of egg weight at the beginning of incubation. ${ }^{a, b}$ Means in the same column with different superscripts are significantly different ( $p<0.05$ ). 
Table 3 - Chick weight at hatching and incubation length of red-legged partridge eggs according to incubation temperature during the hatching phase

\begin{tabular}{|c|c|c|c|c|c|c|c|c|c|}
\hline \multirow{2}{*}{$\begin{array}{l}\text { Temperature during the } \\
\text { hatching period } \\
\left({ }^{\circ} \mathrm{C}\right)\end{array}$} & \multirow{2}{*}{$\begin{array}{c}\text { Number of chicks } \\
\text { hatched }\end{array}$} & \multirow{2}{*}{$\begin{array}{c}\text { Chick weight at } \\
\text { hatching } \\
\text { (g, Mean } \pm \text { SEM) }\end{array}$} & \multicolumn{7}{|c|}{$\begin{array}{l}\text { Incubation length } \\
\text { (d) }\end{array}$} \\
\hline & & & Mean \pm SEM & Variance & $\mathrm{CV}^{1}(\%)$ & $\begin{array}{c}\text { Skewness } \\
\left(g_{1}\right)\end{array}$ & $\begin{array}{c}\text { Kurtosis } \\
\left(g_{2}\right)\end{array}$ & Min & Max \\
\hline 37.0 & 30 & $13.94 \pm 0.23^{\mathrm{ab}}$ & $23.32 \pm 0.11$ & $0.39^{x}$ & 2.67 & -0.38 & -0.25 & 22.00 & 24.50 \\
\hline 37.4 & 38 & $13.46 \pm 0.15^{b}$ & $23.26 \pm 0.07$ & $0.17^{y}$ & 1.78 & 2.31 & 7.30 & 23.00 & 25.00 \\
\hline 37.8 & 28 & $14.07 \pm 0.16^{\mathrm{a}}$ & $23.11 \pm 0.06$ & $0.10^{z}$ & 1.36 & 3.64 & 14.68 & 23.00 & 24.50 \\
\hline Total & 96 & $13.79 \pm 0.11$ & $23.23 \pm 0.05$ & 0.22 & 2.02 & 0.97 & 2.36 & 22.00 & 25.00 \\
\hline$p$ value & & 0.040 & 0.052 & & & & & & \\
\hline
\end{tabular}

${ }^{1} \mathrm{CV}$ : Coefficient of variation. ${ }^{a, b}$ Means in the same column with different superscripts are significantly different $(p<0.05) .{ }^{x-2}$ Variances in the same column with different superscripts are significantly different $(p<0.05)$.

al., 2014a, 2014b, 2014c). Although eggs randomly allocated to the experimental batch incubated at $37.4^{\circ} \mathrm{C}$ during the hatching period showed lower initial weight and, consequently, lost less weight during the incubation than eggs of the other treatments, egg weight loss percentage was not different among the experimental batches. This is obvious since the temperature was modified among treatments on day 20 of incubation, after eggs were weighed to calculate egg weight loss percentage. Our result in terms of egg weight loss percentage partly agree with Gómez-de-Travecedo et al. (2014c), who found a nonlinear progression for this parameter in $A$. rufa when lowering the incubation temperature from 37.8 to $37.5^{\circ} \mathrm{C}$ between days 18 and 22 of incubation.

Mean chick weight at hatching found in this trial are consistent with that described for red-legged partridges in captivity (14.0-14.3 g, according to Gómez-de-Travecedo et al., 2014a, 2014b, 2014c). Chick weight did not follow a linear relationship with the incubation temperature during the hatching period; thus, chicks hatched from eggs incubated at $37.4^{\circ} \mathrm{C}$ showed lower weight than chicks hatched from eggs incubated at $37.8^{\circ} \mathrm{C}$ during the hatching phase, while chicks from eggs incubated at $37.0^{\circ} \mathrm{C}$ showed an intermediate weight. As confirmed by the positive correlation among the chick weight at hatching and the initial egg weight, the hatchling weight differences observed between treatments were due to the differences in initial egg weight, as the eggs incubated at $37.4^{\circ} \mathrm{C}$ were lighter than eggs of the other experimental batches. This agrees with Traldi et al. (2011), who demonstrated in broilers that hatchling weight is influenced by egg weight. Our results do not agree, however, with those of Gómezde-Travecedo et al. (2014c), who did not found hatchling weight differences when lowering the incubation temperature from 37.8 to $37.5^{\circ} \mathrm{C}$ between days 18 and 22 of incubation in red-legged partridges.
The mean incubation period found in this trial matched the 23.4-d period described by GonzálezRedondo et al. (2012) for the artificial incubation of this species. The marginal tendency $(p<0.1$; Table 3$)$ of shorter incubation length when incubation temperature increased during the hatching phase agrees with the shorter incubation length found by Gómez-deTravecedo et al. (2014c), when delaying the change of the incubation temperature from to 37.8 to $37.5^{\circ} \mathrm{C}$ between 18 and $22 \mathrm{~d}$ of incubation. This also agrees with informative publications on red-legged partridge game farming stating that higher temperatures during the incubation shorten the incubation period, whereas lower temperatures lengthen it (Cancho, 1991; Setién, 1991). This is because, as temperature decreases at the end of the incubation period, so does the oxygen consumption by the embryo and, consequently, its pace of development, leading to longer incubation periods (French, 1997).

The most relevant finding in this research study was that hatching synchrony improved when the incubation temperature during the hatching period was increased from 37.0 to $37.8{ }^{\circ} \mathrm{C}$. Thus, hatching distribution progressively became very leptokurtic and very positively skewed as the incubation temperature during the hatching phase increased. Taking into account that, depending on specific incubation conditions, hatching can span from day 21.5 to 26 from the beginning of the incubation in red-legged partridges (González-Redondo et al., 2012), the narrow 1.5-d hatching range achieved by the eggs incubated at $37.8^{\circ} \mathrm{C}$ during the hatching phase represents a high level of hatching synchrony. Our results are consistent with the short hatching interval of $36 \mathrm{~h}$ obtained by Gómez-de-Travecedo et al. (2014C) for $A$. rufa eggs incubated at $37.8^{\circ} \mathrm{C}$ for $22 \mathrm{~d}$, in comparison with eggs whose incubation temperature was lowered to $37.5^{\circ} \mathrm{C}$ between day 18 and 21 of incubation. This high hatching synchrony is a behavioral adaptation of $A$. rufa and other precocial 
species that allows the female to quickly leave the nest with its brood as a strategy to minimize predation risks associated to a long stay in the nest as would occur with a wider hatching span (Persson \& Andersson, 1999; González-Redondo et al., 2012).

It is known that the temperature of the avian embryo at the end of the incubation period is higher than at the beginning due to the extra heat generated by the metabolic activity and movement of the chick. As a consequence, heating needs are lower at this late embryonic stage (Decuypere \& Michels, 1992; Molenaar et al., 2010) and it is the reason why, in redlegged partridge farms, a lower temperature is set in the hatcher than in the incubator (Llauradó, 1987; Cancho, 1991; Setién, 1991; Saperas, 1992; GarcíaMartín \& Dalmau, 2003). Our findings, however, demonstrate that the proper choice of the incubation temperature for the hatching period could enable game farms and hatching centers to improve hatchling handling by extracting all them from the hatcher at the same time, minimizing or even avoiding extraction queues. Nevertheless, since the aim of $A$. rufa partridge game farms is to rear healthy and vigorous partridges for release and restocking of hunting reserves, further research should elucidate which of the temperatures within the range investigated provides better postnatal chick growth performance and survival rate.

\section{CONCLUSION}

Incubating red-legged partridge eggs between 37.0 to $37.8^{\circ} \mathrm{C}$ during the hatching period from day 20 of incubation to hatching did not affect the hatchability or the length of the incubation period. However, hatching synchrony improved when the incubation temperature was increased from 37.0 to $37.8^{\circ} \mathrm{C}$.

\section{REFERENCES}

Bagliacca M, Mori B, Gualterio L. Egg laying under artificial photoregulation in the red partridge. In: Proceedings of the 18th World's Poultry Congress; 1988; Nagoya, Japan, p. 657-659.

Cancho M. Incubación. Equipo y técnicas de manejo. Control. In: La perdiz roja. Fundación La Caixa-AEDOS, Barcelona, Spain; 1991. p. 21-27.

Decuypere $\mathrm{E}$, Michels $\mathrm{H}$. Incubation temperature as a management tool: a review. World's Poultry Science Journal 1992;48:28-38.

Ernst RA, Bradley FA, Abbott UK, Craig RM. Egg candling and breakout analysis. ANR Publication 2004;8134. http://anrcatalog.ucdavis.edu/ pdf/8134.pdf. Accessed June 20th, 2014.

French NA. Modelling incubation temperature: The effects of incubator design, embryonic development, and egg size. Poultry Science 1997;76:124-133.

French NA. Effect of short periods of high incubation temperatures on hatchability and incidence of embryo pathology of turkey eggs. British Poultry Science 2000;41:377-382.
García-Martín E, Dalmau A. Reproducción de la perdiz roja y la codorniz. In: Reproducción e incubación en Avicultura. Real Escuela de Avicultura, Arenys de Mar, Spain; 2003. p. 457-495

Gómez-de-Travecedo P, Caravaca FP, González-Redondo P. Effects of storage temperature and length of the storage period on hatchability and performance of red-legged partridge (Alectoris rufa) eggs. Poultry Science 2014a;93:747-754.

Gómez-de-Travecedo P, Caravaca FP, González-Redondo P. Effects of prestorage incubation of red-legged partridge (Alectoris rufa) eggs on hatchability and incubation length. International Journal of Agriculture and Biology 2014b;16:513-520.

Gómez-de-Travecedo P, Caravaca FP, González-Redondo P. Effects of the time to change from incubation to hatching temperature on the artificial incubation of red-legged partridge (Alectoris rufa) eggs. Spanish Journal of Agricultural Research, 2014c;12:727-731.

González-Redondo P. Influence of the laying date on the fertility and hatchability of red-legged partridge (Alectoris rufa) eggs. Journal of Applied Poultry Research 2006;15:579-583.

González-Redondo P. Effect of long-term storage on hatchability of redlegged partridge (Alectoris rufa) eggs. Poultry Science 2010;89:379383

González-Redondo P, De la Rosa Sánchez S. Efecto de la duración de la fase de volteo de los huevos de perdiz roja (Alectoris rufa) durante la incubación sobre la tasa de eclosión. ITEA-Información Técnica Económica Agraria 2009;105:291-295.

González-Redondo P, Delgado-Pertíñez M, Toribio S, Ruiz FA, Mena Y Caravaca FP, Castel JM. Characterisation and typification of the redlegged partridge (Alectoris rufa) game farms in Spain. Spanish Journal of Agricultural Research 2010;8:624-633.

González-Redondo P, Gutiérrez-Escobar R, Díaz-Merino R, Panea-Tejera P, Martínez-Domínguez AR. Duración de la incubación artificial en perdiz roja (Alectoris rufa). ITEA-Información Técnica Económica Agraria 2012:108:289-297.

Llauradó L. Incubación artificial de huevos de perdiz. Selecciones Avícolas 1987:29:144-147.

Molenaar R, Reijrink IAM, Meijerhof R, Van Den Brand $H$. Meeting embryonic requirements of broilers throughout incubation: a review. Revista Brasileira de Ciência Avícola 2010;12:137-148.

Mourão JL, Barbosa AC, Outor-Monteiro D, Pinheiro VM. Age affects the laying performance and egg hatchability of red-legged partridges (Alectoris rufa) in captivity. Poultry Science 2010;89:2494-2498.

Paci G, Marzoni M, Benvenuti N, Bagliacca M. Breeding technology of redpartridges: colonies or couples. In: Proceedings of the 19th World's Poultry Congress; 1992; Amsterdam, Netherlands, vol. 3, p. 351-352.

Persson I Andersson G. Intraclutch hatch synchronization in pheasants and mallard ducks. Ethology 1999;105:1087-1096.

Sánchez García-Abad C, Alonso ME, Prieto R, González V، Gaudioso VR Una visión sobre la avicultura para la producción de caza en España. ITEA-Información Técnica Económica Agraria 2009;105:169-183.

Saperas JM. Manejo del huevo de perdiz roja en instalaciones cinegéticas Mundo Ganadero 1992:11:76-78.

Setién M. Producción cinegética: granjas de perdices. In: Manual de ordenación y gestión cinegética (Fuentes A, Sánchez I, Pajuelo L, eds). IFEBA, Badajoz, Spain; 1991. p. 133-152.

Traldi AB, Menten JFM, Silva CS, Rizzo PV, Pereira PWZ, Santarosa J. What determines hatchling weight: breeder age or incubated egg weight? Revista Brasileira de Ciência Avícola 2011:13:283-285. 
